i przekazać następnym pokoleniom. Książka jest ze wszech miar godna polecenia tym wszystkim, którzy cenią język łaciński, literaturę antyczną, średniowieczną i nowożytną oraz zawartą w niej nieprzemijającą mądrość łacińskich przysłów i powiedzeń.

Ks. Krzysztof Burczak - Lublin

Stephan WENINGER, Das Verbalsystem des Altäthiopischen. Eine Untersuchung seiner Verwendung und Funktion unter Berücksichtigung des Interferenzproblems (Veröffentlichungen der Orientalischen Kommission der Akademie der Wissenschaften und der Literatur im Mainz, hrsg. Walther W. Müller, Bd. 47), Wiesbaden 2001, Harrassowitz Verlag, ss. 387.

Omawiana książka jest poprawioną wersją rozprawy habilitacyjnej S. Weningera z 1997 r. na Uniwersytecie Ludwika Maksymiliana w Monachium. Autor po raz pierwszy zastosowal w niej metodę lingwistyczno-noetyczną, wypracowaną przez ośrodek monachijski po II wojnie światowej, dzięki pracom E. Koschmidera i A. Denza, nad klasycznym językiem etiopskim geez. W latach siedemdziesiątych ubiegłego wieku semitolog Adolf Denz na podstawie prac E. Koschmidera zastosował metodę noetyczną do dialektu języka arabskiego zwanego Kwayrisz, a jego uczniowie do innych języków semickich: R. Bartelmus zastosował ją do języka hebrajskiego i aramejsko-biblijjnego, N. Nebes i Ch. Correll do języka arabskiego, M. Streck do języka akkadyjskiego, a S. Bombeck do języka syryjskiego.

$\mathrm{Na}$ czym polega owa nowa metoda językoznawcza (Die Methode der noetischen Sachverhaltsanalyse) (ss. 24-36) wypracowana przez ośrodek monachijski? Metoda ta polega w skrócie na badaniu relacji i czynności jakie zachodzą wobec aktualnego punktu odniesienia mówiącego, który może istnieć w czasie teraźniejszym, przeszłym i przyszłym. Należy tu również wziąć pod uwagę aspekt czynności - dokonany lub niedokonany. Wyróżnia się na przykład jednostkowe i ogólne rodzaje czynności (individuelle, generelle Sachverhalte). Czynności jednostkowe dzielą się na jednorazowe i wielokrotne, które w zależności od czasu mogą być współczesne, przeszłe i przyszłe.

Metodę noetycznej analizy czynności zastosował Weninger do 13 kategorii czasownikowych: qatala, yekattel, yektel, qatilo, qetel, hallo yeqtel, hallawa teqtel, hallo qatilo, kona qatala, kona.yekattel, nabara yekattel, nabara qatilo. Przykłady obrazujące zastosowanie metody noetycznej do wymienionych kategorii czasownikowych zaczerpnął Weninger ze Starego i Nowego Testamentu oraz etiopskiej literatury patrystycznej. Wyniki swych badań przedstawił w czwartym rozdziale Funktionsanalyse (ss. 309-336), z którego dowiadujemy się, jak omawiana kategoria czasownikowa funkcjonuje w świetle analizy noe- 
tycznej i czy wszystkie rodzaje czynności mają zastosowanie. Ostatni rozdział piąty obejmuje wykaz źródeł, cenną bibliografię etiopistyczną, uwzględniającą przede wszystkim problematykę lingwistyczną, indeks rzeczowy i wykaz cytowanych miejsc w źródłach.

Omawiana rozprawa habilitacyjna stanowi bez wątpienia cenny wkład w rozumienie funkcji czasownika, a w związku z tym przyczyni się do dokładniejszego ustalenia znaczenia konkretnego wyrażenia występującego w klasycznym języku etiopskim.

Jerzy Woźniak CM - Wiedeń

\section{Josef TROPPER, Altäthiopisch. Grammatik des Ge'ez mit Übungstexten und Glossar, Elementa Linguarum Orientis 2, Münster 2002, Ugarit Verlag, ss. 309.}

Josef Tropper, docent w Freie Universität Berlin, jest już znanym semitologiem i autorem kilku książek, między innymi z zakresu ugarytologii. Podjął się redagowania nowej serii naukowej razem z Reinhardem Lehmannem (Mainz), poświęconej dawnym językom semickim, celem przygotowania podręczników do ich nauczania, uwzględniając obecny rozwój wspólczesnego językoznawstwa. Omawiana pozycja ukazuje się na obszarze języka niemieckiego po ponad stu latach od ostatnich podręczników do etiopistyki (A. Dillmann, Grammatik der äthiopischen Sprache, Leipzig 1857/1899; F. Praetorius, Aethiopische Grammatik mit Paradigmen Literatur, Chrestomathie und Glossar, Karlsruhe - Leipzig 1886). Jak zaznaczył w przedmowie Tropper, obecna gramatyka nie zastąpi nigdy obszernej gramatyki A. Dillmanna, ale może pomóc studentom i wykładowcom akademickim, gdyż uwzględnia obecny stan wiedzy językoznawczej w etiopistyce. Pisząc tę gramatykę Tropper uwzględnil już osiągnięcia S. Weningera (Das Verbalsystem des Altäthiopischen. Eine Untersuchung seiner Verwendung und Funktion unter Berücksichtigung des Interferenzproblems, Wiesbaden 2001) i zastosował je do opisu kategorii czasownika.

Slownictwo etiopskie Autor podaje w transkrypcji z uwagi na duży stopień trudności przyswojenia sobie tego pisma przez studentów oraz na latwiejsze poznanie struktury języka geez. Autor omawia problemy gramatyczne w następującym porządku: pisownia (ss. 5-16), fonologia (17-42), morfologia - zaimek, rzeczownik, liczebnik, czasownik, partykuły (ss. 43-153), syntaksa wyrazów zaimek, rzeczownik, liczebnik, czasownik, funkcje rzeczowników adwerbialnych i przymiotników odczasownikowych (ss. 154-213), syntaksa zdań - zdanie nominalne i werbalne, Pendenskonstruktion i zdania poboczne (ss. 213-252).

Po omówieniu kategorii gramatycznych Autor zapoznaje czytelnika ze stroną praktyczną, a mianowicie podaje 6 tekstów (J 1, 1-18); Mt 6, 9-13, cały rozdz. 5, Hen 1, 1-9; Jub 50, 12-13; Sena fetrat 1-7) w oryginalnym języku ge'ez 